\title{
Balloon Sacroplasty as a Palliative Pain Treatment in Patients with Metastasis-Induced Bone Destruction and Pathological Fractures
}

\section{Ballonsakroplastie als palliative Schmerztherapie bei Patienten mit metastasenbedingten ossären Destruktionen und pathologischen Frakturen}

Authors

Affiliations
R. Andresen ${ }^{1}$, S. Radmer² , C. W. Lüdtke ${ }^{1}$, P. Kamusella ${ }^{1}$, C. Wissgott ${ }^{1}$, H. C. Schober ${ }^{3}$

Institute of Diagnostic and Interventional Radiology/Neuroradiology, Westkuestenklinikum Heide, Academic Teaching Hospital of the Universities of Kiel, Luebeck and Hamburg, Heide

2 Orthopedic Surgery and Traumatology, Center of Orthopedics, Berlin

3 Department of Internal Medicine, Municipal Hospital Suedstadt Rostock, Academic Teaching Hospital of the University of Rostock
Key words

- balloon sacroplasty

- metastasis-induced bone destruction

- interventional pain therapy

palliative therapy

os sacrum $\begin{array}{ll}\text { received } & 7.5 .2013 \\ \text { accepted } & 14.12 .2013\end{array}$

\section{Bibliography}

Dol http://dx.doi.org/

10.1055/s-0033-1356418

Published online: 20.2.2014

Fortschr Röntgenstr 2014; 186:

881-886 @ Georg Thieme

Verlag KG Stuttgart · New York .

ISSN 1438-9029

\section{Correspondence}

Prof. Dr. Reimer Andresen

Institut für Diagnostische und Interventionelle Radiologie/

Neuroradiologie,

Westküstenklinikum Heide, Akademisches Lehrkrankenhaus der Universitäten Kiel, Lübeck und Hamburg

Esmarchstraße 50

25746 Heide

Germany

Tel.: ++49/0481/7 852401

Fax: ++ 49/0481/7 852409

randresen@wkk-hei.de

\section{Zusammenfassung \\ $\nabla$}

Ziel: Bei einem Metastasenbefall des Os sacrum mit Destruktion und konsekutiver pathologischer Fraktur, stehen stärkste invalidisierende Schmerzen im Vordergrund. Es sollte die Durchführbarkeit, Sicherheit und Schmerzentwicklung einer Zementaugmentation überprüft werden.

Material und Methoden: Bei 10 Patienten mit einer metastasenbedingten ossären Destruktion des Os sacrum wurde eine CT-gesteuerte Ballonsakroplastie durchgeführt. Nach Festlegung der Eingangsebene erfolgte das Vorbringen eines Kirschner-Drahts bis in die zentrale Tumorläsion über die kurze- oder transiliakale Achse. Über den Draht wurde dann eine Hohlnadel eingebracht. Hierüber wurde ein Ballonkatheter eingeführt und unter CT-Kontrolle mehrmals in- und deflatiert. In den vorgefertigten Hohlraum erfolgte dann die PMMA-Zementapplikation. Den Abschluss der Intervention bildete eine SpiralCT-Kontrolle in Dünnschichttechnik. Die Schmerzintensität wurde vor der Intervention, am 2. postoperativen Tag und 6 Monate post interventionem mittels visueller Analogskala (VAS) bestimmt. Abschließend wurde die Patientenzufriedenheit erfragt.

Ergebnisse: Bei allen Patienten ließ sich die Ballonsakroplastie technisch gut durchführen. Es zeigte sich im Kontroll-CT eine zentrale Zementverteilung in der Tumorläsion. Im Durchschnitt wurden pro versorgter Läsion $6+/-1,78(4-10)$ ml PMMA-Zement eingebracht. Bei allen Patienten fand sich eine signifikante $(p<0,001)$ Schmerzreduktion nach VAS von $9,3+\mid-0,67$ $(8-10)$ präinterventionell auf $2,7+/-1,28(1-5)$ am 2. postoperativen Tag und auf $2,9+\mid-0,81$ $(2-5) 6$ Monate post interventionem. Alle Patienten konnten nach der Intervention remobilisiert und den weiter geplanten therapeutischen Maßnahmen zugeführt werden.

\section{Abstract \\ $\nabla$}

Purpose: In the case of metastatic involvement of the sacrum with destruction and consecutive pathological fracture, intense disabling pain is one of the defining factors. The feasibility, safety and pain development with cement augmentation were to be investigated.

Materials and Methods: CT-guided balloon sacroplasty was conducted in 10 patients with metastasis-induced bone destruction of the sacrum. After establishment of the entry point, a K-wire was first introduced as far as the central tumor lesion via the short, or transiliac axis. A cannula was then positioned over the wire. Under CT guidance, a balloon catheter was introduced through the cannula and inflated and deflated several times. The PMMA cement was then injected into the preformed cavity. The procedure was completed by a spiral CT control using the thin-slice technique. Pain intensity was determined using a visual analog scale (VAS) before the procedure, on the 2nd postoperative day and 6 months after the intervention. Finally, the patients were asked to state how satisfied they were.

Results: Balloon sacroplasty was technically feasible in all patients. The control CT scan showed central distribution of the cement in the tumor lesion. On average $6+/-1.78(4-10) \mathrm{ml}$ of PMMA cement were introduced per treated lesion. A significant $(\mathrm{p}<0.001)$ reduction in pain according to the VAS occurred in all patients from $9.3+/-0.67(8-10)$ pre-operatively to $2.7+\mid-1.28(1-5)$ on the 2 nd postoperative day and $2.9+/-0.81(2-5) 6$ months after the intervention. All of the patients were remobilized after the procedure and underwent the further therapeutic measures as planned.

Conclusion: Balloon sacroplasty is a helpful therapeutic option in the overall palliative treatment of patients with tumor-induced destruction. It is a safe and practicable procedure that markedly reduces disabling pain. 
Schlussfolgerung: Die Ballonsakroplastie ist zur Behandlung von Patienten mit tumorbedingten Destruktionen eine hilfreiche Therapieoption im palliativen Gesamtkonzept. Sie ist eine sichere und gut durchführbare Prozedur, welche die invalidisierenden Schmerzen deutlich reduziert.

Kernaussagen:

- Die Ballonsakroplastie ist bei ossären Destruktionen ein sicheres Verfahren zur Zementaugmentation

- Mit der Ballonsakroplastie lassen sich invalidisierende Kreuzschmerzen signifikant reduzieren

- Die Ballonskroplastie ist eine hilfreiche Therapieergänzung im palliativen Gesamtkonzept
Key points:

- Balloon sacroplaty is a safe method of cement augmentation for osseous destruction

- With balloon sacroplasty debilitating lower back pain can be significantly reduced

- Balloon sacroplasty is a helpful supplement in palliative therapy

Citation Format:

- Andresen R, Radmer S, Lüdtke CW et al. Balloon Sacroplasty as a Palliative Pain Treatment in Patients with MetastasisInduced Bone Destruction and Pathological Fractures. Fortschr Röntgenstr 2014; 186: 881-886

\section{Introduction}

$\nabla$

In the advanced stages of malignant diseases such as breast cancer, prostate cancer, lung cancer, renal cell cancer, thyroid cancer, multiple myeloma and lymphoma, metastases in the axial skeleton are common [1]. Bone metastases are the most common malignant bone disease in adults. They have a negative impact on the quality of life and worsen the patient's prognosis [1]. If the sacrum is affected with destruction and consecutive pathological fracture, the cardinal symptom is disabling pain in the region of the lower lumbar spine and pelvis. As in the case of insufficiency fractures, conservative treatment by means of bed rest and analgesic therapy rarely achieves a satisfactory reduction in pain. Pain-related immobility can lead to the development of decubitus ulcers, venous thrombosis and pulmonary embolism, pneumonia and further deterioration of the musculoskeletal system [2]. The aim of interventional treatment is a rapid reduction in pain, with a resulting increase in mobility and improvement in quality of life [3], so that the further necessary therapeutic measures, such as chemotherapy, hormone and radiotherapy, can then be performed in an overall palliative concept. Additional pharmacotherapy with bisphosphonates is considered to be obligatory. It minimizes the loss of bone mass and delays the development of pathological fractures, reduces metastasis-induced bone pain and possibly increases the apoptosis rate of metastasized tumor cells [1]. Analogous to percutaneous cement augmentation in vertebral body metastases, for which very good pain reduction has been described [4-6], there have been reports of good experience with cement augmentation of the sacrum in osteoporo- sis-induced insufficiency fractures $[2,3,7]$ and good initial results in the case of malignant destruction, whereby sacroplasty analogous to the vertebroplasty technique is mostly applied here [8-17].

We report on our first clinical experience with the application of balloon sacroplasty in patients with metastasis-induced destruction and provide an overview of the relevant literature concerning cement augmentation in the os sacrum.

\section{Materials and Methods \\ $\nabla$}

CT-guided balloon sacroplasty was carried out in 5 female and 5 male patients with metastasis-induced bone destruction of the os sacrum, with an average age of $64.3+/-10.06(49-79)$ years ( $\bullet$ Table 1 ). The volume of each lesion was measured on the CT scans. The indication for cement augmentation was established in an interdisciplinary case conference with oncologists/ specialists in internal medicine, orthopedic/trauma surgeons, neurosurgeons and interventional radiologists.

The procedure was performed under intubation anesthesia and anesthetic monitoring. Patients were placed in the prone position in the CT scanner. Single-shot antibiotic prophylaxis was routinely given (cefazoline $2 \mathrm{~g}$ i. v.). After establishment of the entry point and usual preparation, a Kirschner wire was first introduced as far as the central tumor lesion via the short or transiliac axis ( Fig. 1 - 3). A cannula was then positioned over the wire. Under CT guidance, a balloon catheter was introduced through the cannula and inflated and deflated several times, partly over-

\begin{tabular}{|c|c|c|c|c|}
\hline & sex/age & primary tumor & $\begin{array}{l}\text { location of the lesion in the sacrum/tumor } \\
\text { volume }\end{array}$ & approach [3] \\
\hline pat. 1 & 58 yrs./f & multiple myeloma & $\begin{array}{l}\text { bilateral: lateral mass right } / 6.8 \mathrm{ml} \text {, lateral } \\
\text { mass with involvement of the intermediate } \\
\text { zone left } / 8 \mathrm{ml}\end{array}$ & short axis bilateral \\
\hline pat. 2 & $52 \mathrm{yrs} . / \mathrm{f}$ & multiple myeloma & lateral mass left/ $6.6 \mathrm{ml}$ & short axis \\
\hline pat. 3 & $69 \mathrm{yrs} . / \mathrm{m}$ & multiple myeloma & lateral mass right/ $7.1 \mathrm{ml}$ & short axis \\
\hline pat. 4 & $74 \mathrm{yrs} . / \mathrm{m}$ & multiple myeloma & $\begin{array}{l}\text { bilateral with involvement of the vertebral } \\
\text { body zone/right: } 8 \mathrm{ml} \text {, left } 11.7 \mathrm{ml}\end{array}$ & transiliac bilateral \\
\hline pat. 5 & 49 yrs./f & breast carcinoma & lateral mass left/ $7.3 \mathrm{ml}$ & short axis \\
\hline pat. 6 & 63 yrs./f & renal cell carcinoma & lateral mass right/ $8.8 \mathrm{ml}$ & short axis \\
\hline pat. 7 & 57 yrs./m & urothelial carcinoma & lateral mass right/ $7.1 \mathrm{ml}$ & short axis \\
\hline pat. 8 & $69 \mathrm{yrs} . / \mathrm{m}$ & hepatocellular carcinoma & $\begin{array}{l}\text { lateral mass right up to the vertebral body } \\
\text { zone } / 11.3 \mathrm{ml}\end{array}$ & transiliac \\
\hline pat. 9 & 79 yrs./f & lung carcinoma & vertebral body zone/ $10.8 \mathrm{ml}$ & transiliac \\
\hline pat. 10 & $73 \mathrm{yrs} . / \mathrm{m}$ & lung carcinoma & $\begin{array}{l}\text { lateral mass left with spread up to the sacral } \\
\text { vertebral body } 52 / 12.1 \mathrm{ml}\end{array}$ & transiliac \\
\hline
\end{tabular}

Table 1 Patient characteristics.

Tab. 1 Charakteristik der

Patienten 
lapping in a central to peripheral direction. The polymethyl methacrylate (PMMA) cement was then injected into the preformed cavity with low pressure under CT single slice guidance. The procedure was completed by a spiral CT control using the thin-slice technique with coronal and sagittal reformation with a 2-mm slice thickness.

Examples of cement augmentation via the short axis are shown in - Fig. 2a-c and via the transiliac approach in 8 Fig. 3a-d.

Pain intensity was determined using a visual analog scale (VAS) before the procedure, on the 2nd postoperative day and 6 months after intervention. The results were tested for significance by rank variance analysis for several connected samples according

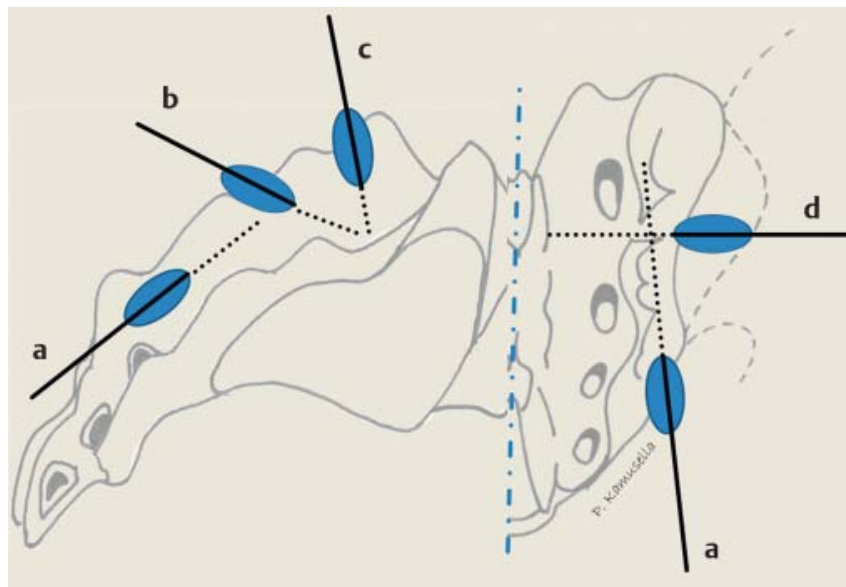

Fig. 1 Illustration of the possible approaches for gaining access to a fracture or bone destruction zone in the sacrum. a shows the approach via the long axis, $\mathbf{b}$ via the angulated short axis, $\mathbf{c}$ via the short axis and $\mathbf{d}$ via the transiliac axis. All of the metastasis-induced lesions could be effectively accessed via the short or transiliac axis.

Abb. 1 Illustration der möglichen Zugangswege zur Erreichung einer Fraktur oder ossären Destruktionszone im Os sacrum. Mit a ist der Zugang über die lange Achse, mit b über die angulierte kurze Achse, mit c über die kurze Achse und mit d über die transiliakale Achse dargestellt. Alle metastasenbedingten Läsionen ließen sich gut über die kurze oder transiliakale Achse erreichen. to Friedman. All values are stated as mean $+/$ - standard deviation and in their range.

Finally, the patients were asked to state how satisfied they were after the intervention.

\section{Results}

$\nabla$

The balloon sacroplasty was performed successfully from a technical point of view in all patients. All of the sacral lesions could be accessed via the short or transiliac axis ( $\bullet$ Fig. $1-3, \bullet$ Table 1 ). The control CT scan showed central distribution of the cement in the tumor lesion. Leakage of the cement in the direction of the neuroforamina, iliosacral joints or visceral surface with sacral plexus could be ruled out. On average $6+/-1.78(4-10) \mathrm{ml}$ of PMMA cement were introduced per lesion treated. The volume of the lesions ranged from $6.6-12.1 \mathrm{ml}$. A significant $(p<0.001)$ reduction in pain was observed in the VAS in all patients on the 2nd postoperative day ( $\bullet$ Fig. 4), whereby the pain was reduced on average from $9.3+/-0.67(8-10)$ pre-operatively to $2.7+/-$ $1.28(1-5)$ score points on the $2^{\text {nd }}$ postoperative day and to $2.9+/-0.81(2-5) 6$ months postoperatively. All of the patients were remobilized after the procedure and underwent the further therapeutic measures as planned. Two patients (pat. 8 and pat. 9) died 3 and 5 months post-intervention due to their underlying disease.

With regard to the question of patient satisfaction, all of the patients were very satisfied. They all felt that their quality of life had improved and said that they would undergo the intervention again without reservation.

\section{Discussion \\ $\nabla$}

The experience gained to date with cement augmentation analogous to the vertebroplasty technique shows good technical feasibility with sufficient safety and convincing post-interventional pain reduction in patients with metastasis-induced bone destruction [10-19]. The mechanism of the pain reduction after cement introduction is not yet sufficiently understood. Stabilization of the destroyed bone by the cement filling appears to be the
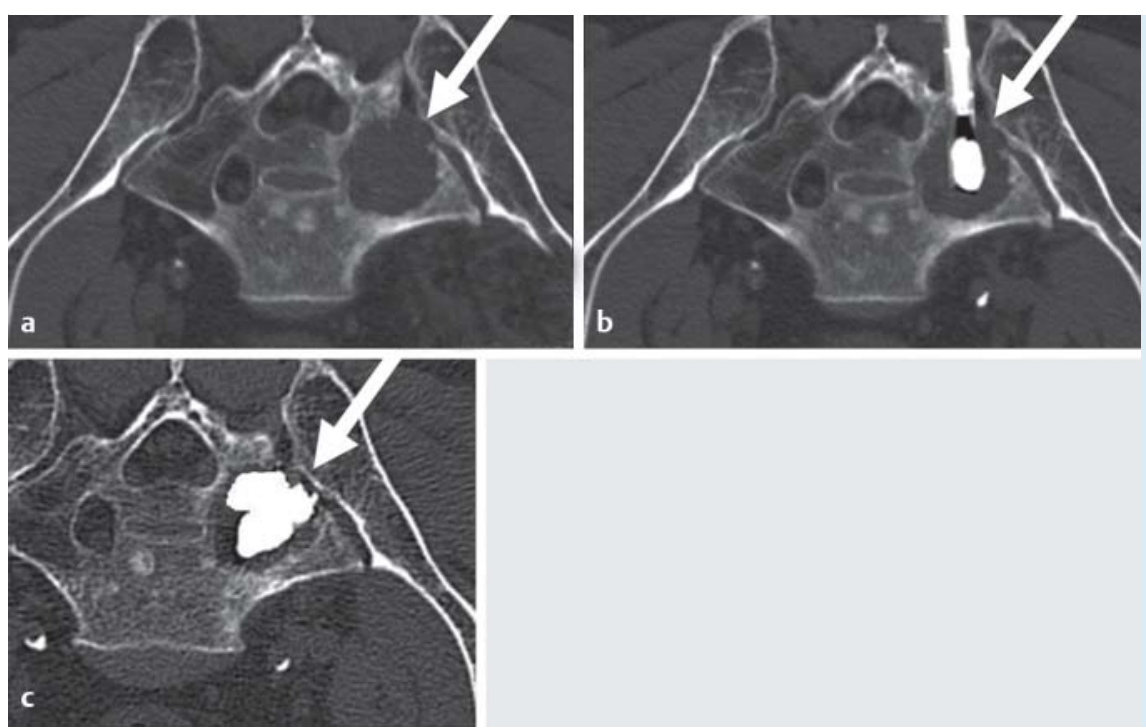

Fig. 2 a-c ( $($ Table 1, Pat. 7) a Axial CT slice of the os sacrum: image of an osteolysis in the lateral mass on the right. $\mathbf{b}$ Inflated balloon centrally in the bone destruction of the right lateral mass. The approach was via the short axis. c Centrally positioned cement filling in the metastasis-induced osteolysis. There is no evidence of cement leakage.

Abb. 2 a-c ( $\odot$ Tab. 1, Pat. 7) a Axiales CT-Schnittbild des Os sacrum: Darstellung einer Osteolyse in der Massa lateralis rechts. $\mathbf{b}$ Inflatierter Ballon zentral in der ossären Destruktion der rechten Massa lateralis. Der Zugang erfolgte über die kurze Achse. c Zentral liegende Zementplombe in der metastasen bedingten Osteolyse. Es findet sich kein Anhalt für eine Zementleckage. 

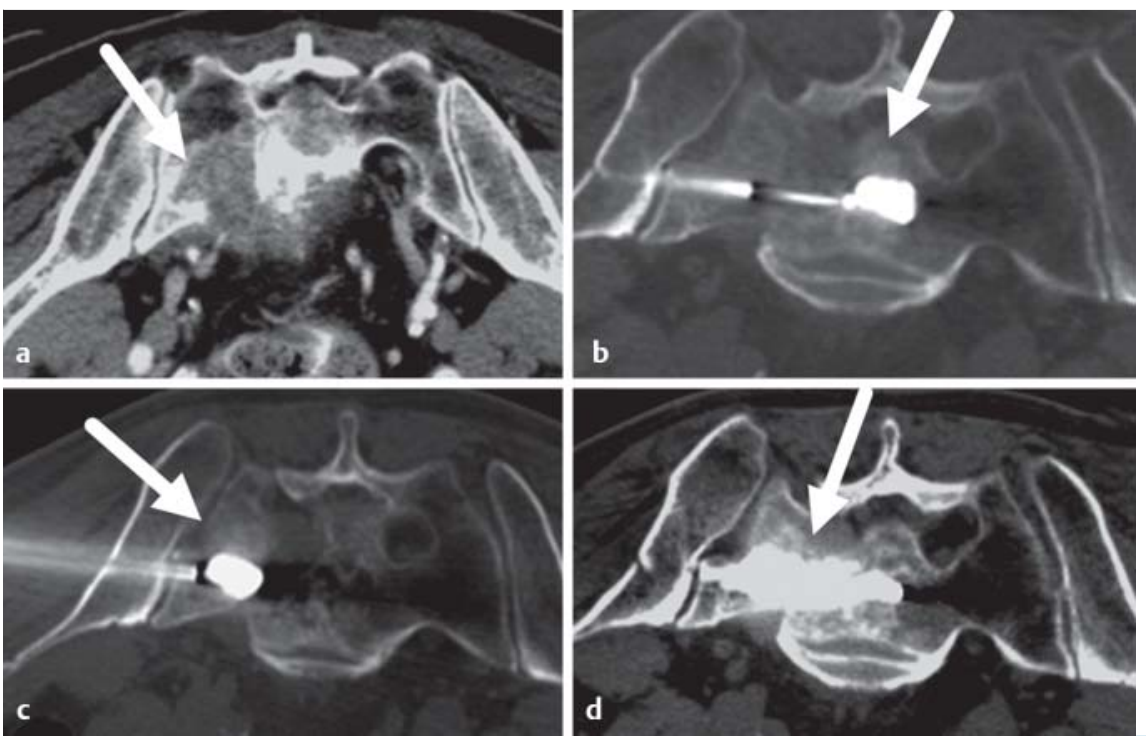

Fig. 3 a-d ( $\triangle$ Table 1, Pat. 10) a Axial CT slice of the os sacrum: tumor infiltration of the sacrum on the left with infiltration of the lateral mass, the transforaminal zone up to the sacral vertebral body. The tumor has destroyed and exceeded the central and dorsal cortical boundary. $\mathbf{b}$ Inflated balloon in the sacral vertebral body via a transiliac approach from the left. The balloon is inflated and deflated several times, thus shifting it from a central position laterally. $\mathbf{c}$ Inflated balloon after having been shifted from the central zone into the area of the lateral mass on the left. Roughly the same plane as in Fig. 2a, the cannula inserted via a transiliac approach and the inflated balloon are captured centrally. For a better understanding, - Fig. 2a, b have been reflected vertically, the intervention was performed in the prone position. $\mathbf{d}$ The post-interventional control CT scan shows the cement distribution, whereby the lateral mass, the transforaminal zone and the sacral vertebral body have been augmented. There is no evidence of leakage.

Abb.3 a-d ( Tab. 1, Pat 10) a Axiales CT-Schnittbild des Os sacrum: Tumorinfiltration des Os sacrum links mit Infiltration der Massa lateralis, der transforaminalen Zone bis hin zum Sakralwirbelkörper. Der Tumor destruiert und überschreitet die ventrale und dorsale kortikale Begrenzung. b Inflatierter Ballon im Sakralwirbelkörper über einen transiliakalen Zugangsweg von links. Der Ballon wird mehrere Male in- und deflatiert und hierbei von zentral nach lateral verlagert. c Inflatierter Ballon nach Verlagerung aus der zentralen Zone in den Bereich der Massa lateralis links. Annähend gleiche Ebene wie in $\bullet \mathbf{A b b}$. 2a, die transiliakal eingebrachte Hohlnadel und der inflatierte Ballon sind zentral getroffen. Zum besseren Verständnis wurden die $\bullet \mathbf{A b b}$. $\mathbf{2 a}$, b vertikal gespiegelt, die Intervention erfolgte in Bauchlage. $\mathbf{d}$ Im postinterventionellen Kontroll-CT Darstellung der Zementverteilung, wobei die Massa lateralis, die transforaminale Zone und der Sakralwirbelkörper augmentiert sind. Eine Leckage ist nicht nachweisbar.

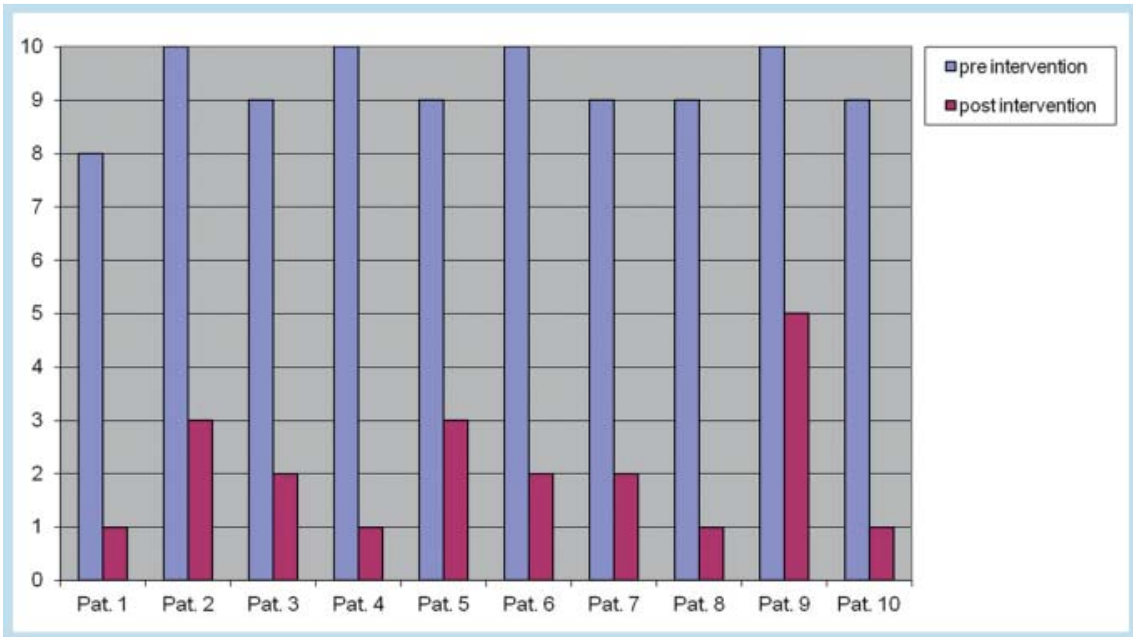

Fig. 4 Illustration of the course of the patients pain according to the VAS.

Abb. 4 Darstellung des Schmerzverlaufes der Patienten nach VAS.

main reason for the pain reduction experienced immediately after the intervention, while the thermal effect caused by cement hardening also plays a role $[11,20]$.

Cement augmentation analogous to kyphoplasty is less well known at present, but shows comparably good results with regard to pain reduction $[8,9,21]$. Using a balloon catheter, a central cavity is created in the lesion for the introduction of the cement, whereby a compaction of peripheral tumor tissue and the adjacent pathological fracture zone closes possible fissures [8], and thus makes it more difficult for cement to leak in the direction of the neuroforamina, iliosacral joints and visceral surface of the sacrum. Reduction of cement leakages represents an advantage of sacro-kyphoplasty [3, 9] over sacro-vertebroplasty [22, 23 ] in patients with insufficiency fractures as well as in patients with osseus destruction. Leakages can cause severe complications such as radiculopathies with strong pain, which in the 


\begin{tabular}{|lcll|}
\hline author & number of patients & primary tumor & follow-up/pain reduction \\
\hline Basile et al. [18] & 8 & multiple myeloma & 3 -27 months, yes \\
\hline Butler et al. [7] & 1 & multiple myeloma & 2 weeks, yes \\
\hline Wee et al. [13] & 2 & multiple myeloma/ renal cell carcinoma & $3-6$ months, yes \\
\hline Hierholzer et al. [11] & 1 & lung carcinoma & 2 months, yes \\
\hline Masala et al. [12] & 1 & lung carcinoma & 4 months, yes \\
\hline Shah et al. [9] & 5 & $\begin{array}{l}\text { lung carcinoma/ neuroendocrine } \\
\text { carcinoma }\end{array}$ & 2 days, yes \\
\hline Zhang et al. [14] & 2 & lung carcinoma/ lymphoma & 12 - 20 weeks, yes \\
\hline Toro et al. [31] & 1 & hepatocellular carcinoma & 2 months, yes \\
\hline Uemura et al. [20] & 1 & hepatocellular carcinoma & 10 days, yes \\
\hline Georgy et al. [15] & 11 & breast carcinoma & 4 weeks, yes \\
\hline Valencia-Anguita et al. [19] & 1 & breast carcinoma & 6 months, yes \\
\hline Lüdtke et al. [8] & 1 & rectal carcinoma & 2 days, yes \\
\hline Dehdashti et al. [32] & 1 & not known & 2 days, yes \\
\hline Sun et al. [16] & 7 & $\begin{array}{l}3 \text { lung carcinomas, } \\
2 \text { breast carcinomas, }\end{array}$ & 1 month, yes \\
& & $\begin{array}{l}1 \text { renal cell carcinoma, } \\
1 \text { hepatocellular carcinoma }\end{array}$ & \\
\hline Kortman et al. [17] & 35 & $\begin{array}{l}24 \text { metastases from different } \\
\text { malignant tumors, } \\
11 \text { multiple myelomas }\end{array}$ & 1 month, yes \\
\hline
\end{tabular}

Table 2 Literature overview of sacroplasties in patients with malignant tumors.

Tab. 2 Literaturübersicht von Sakroplastien bei Malignompatienten worst case have to be treated with surgical decompression [23]. In our own patients as well as the sacrokyphoplasty cases published to date, no leakage was seen in the post-operative imaging even though the degree of bone destruction varied considerably $[8,9,21]$, which in our view is a great advantage of the balloon technique. Cement augmentation using a vesselplasty balloon can possibly be guided even more accurately in tumor tissue with a pronounced soft tissue component and destruction-related loss of bony landmarks, which can reduce the risk of leakages even further [24]. The complex anatomy of the sacrum must be taken into account when performing sacroplasty [25] and visualization of the bone destruction and fracture analysis by means of $\mathrm{CT}$ are absolutely necessary before the intervention. This makes it possible to plan the approach pre-operatively. All lesions can be accessed using an approach via the short, modified angulated short, long, or transiliac axis, and augmented with sufficient cement $[3,8,9,26-28]$. The CT-guided insertion of the needle system and the balloon catheter can be achieved safely with appropriate practice and does not differ from the treatment of insufficiency fractures. The cement application can be guided under simultaneous conventional fluoroscopy using an additional C-arm or CT-fluoroscopy [16, 29, 30], but this does not appear to be absolutely necessary if the approach is taken via the short axis $[3,13,30,31]$ or transiliac axis $[3,8]$. The approach via the transiliac axis is easy to guide in the CT gantry as a plane-parallel alignment to the ray path, whereby, depending on the position and extent of the tumor destruction, the lateral, transforaminal and central zone are easy to access in the sacrum ( $\bullet$ Fig.3) [8, 16]. In view of the generally widespread structural rarefaction and destruction of bone, which reduce the bone landmarks, we consider an intervention solely under fluoroscopy $[9,14]$ to be too inaccurate and very risky, as signs of leakage cannot be recognized in good time.

Metastases are the most common malignant lesions in the sacrum [32]. Currently, reports of around 80 patients with metastasis-induced osteolyses who were treated with cement augmentation in the sacrum can be found in the literature from throughout the world. They involved metastases from primary malignant tumors of multiple myeloma $[7,13,17,18]$, lung cancer $[9,11,12$,
$14,16]$, renal cell cancer $[13,16]$, hepatocellular cancer $[16,20$, $33]$, breast cancer $[15,16,19]$, lymphoma [14], rectal cancer [8], neuroendocrine cancer [9] and a cancer of unknown primary origin or a tumor not stated $[17,34]$ ( $\diamond$ Table 2 ). It must be taken into account that metastases from renal cell cancer and hepatocellular cancer [30] are strongly vascularized and tend to bleed during the intervention.

In addition, the primarily benign lesions that were found included a symptomatic cyst [17], two symptomatic aggressive sacral hemangiomas $[17,20]$ and two actinically related osteonecroses with consecutive pathological fracture [7, 35].

In our patients and the published cases [7-9, $11-20,33-36]$, a significant and sustained reduction in the disabling pain was observed ( $\bullet$ Fig. 4 ), whereby no major difference was found compared with the data of patients treated for insufficiency fractures $[3,8,9,17]$. Long-term follow-up in this kind of treatment is extremely rare. In our patients the pain reduction lasted up to 6 months postoperatively. Basile et al. [18] and Wee et al. [13] show similar results for patients with multiple myeloma.

A further advantage for cancer patients is that the alleviation of the strong pain symptoms makes it much easier to perform other necessary measures such as radiotherapy and chemotherapy.

\section{Conclusion}

Cement augmentation is a helpful therapeutic option in the overall palliative concept for patients with tumor-related destruction of the os sacrum. In the form of balloon sacroplasty, it is a safe and practicable procedure that markedly reduces disabling pain and thus increases the patient's quality of life. This markedly improves the feasibility of other necessary therapeutic measures. 


\section{Clinical Relevance of the Study}

In a comprehensive palliative therapy concept, balloon sacroplasty is an important supplement which significantly reduces the debilitating pain that is associated with metastatic osseus destruction. Cement leakages can be minimized by the use of a balloon catheter.

\section{References}

1 Roodmann GD. Mechanisms of bone metastasis. N Engl J Med 2004; 350: $1655-1664$

$2 \mathrm{He}$ (GM. Sakroplastie zur Behandlung von Insuffizienzfrakturen des Sakrums. Unfallchirurg 2006; 109: 681-686

3 Andresen R, Radmer S, Kamusella P et al. Interventionelle Schmerztherapie mittels Ballon-Kyphoplastie bei Patienten mit osteoporosebedingten Insuffizienzfrakturen des Os sacrum. Fortschr Röntgenstr 2012; 184: $32-36$

4 Calmels V, Vallee JN, Rose $M$ et al. Osteoblastic and mixed spinal metastases: evaluation of the analgesic efficacy of percutaneous vertebroplasty. Am J Neuroradiol 2007; 28: 570-574

5 Pfugmacher R, Taylor R, Agarwal A et al. Balloon kyphoplasty in the treatment of metastatic disease of the spine: a 2-year prospective evaluation. Eur Spine J 2008; 17: 1042-1048

6 Qian Z, Sun Z, Yang H et al. Kyphoplasty for the treatment of malignant vertebral compression fractures caused by metastases. J Clin Neurosci 2011; 18: $763-767$

7 Butler CL, Given CA 2nd, Michel SJ et al. Percutaneous sacroplasty for the treatment of sacral insufficiency fractures. Am J Roentgenol 2005; 184: $1956-1959$

8 Lüdtke CW, Kamusella P, Andresen R. Schmerzbehandlung mittels CTgesteuerter Ballonsakroplastie bei einem Patienten mit einer pathologischen Fraktur. Fortschr Röntgenstr 2012; 184: 578-580

9 Shah RV. Sacral kyphoplasty for the treatment of painful sacral insufficiency fractures and metastases. Spine J 2012; 12: 113-120

10 Marcy PY, Palussière J, Descamps B et al. Percutaneous cementoplasty for pelvic bone metastasis. Support Care Cancer 2000; 8: 500-503

11 Hierholzer J, Anselmetti G, Fuchs $\mathrm{H}$ et al. Percutaneous osteoplasty as a treatment for painful malignant bone lesions of the pelvis and femur. J Vasc Interv Radiol 2003; 14: $773-777$

12 Masala S, Konda D, Massari F et al. Sacroplasty and iliac osteoplasty under combined CT and fluoroscopic guidance. Spine 2006; 31: 667-669

13 Wee B, Shimal A, Stirling AJ et al. CT-guided sacroplasty in advanced sacral destruction secondary to tumour infiltration. Clinical Radiology 2008; 63: $906-912$

14 Zhang J, Wu CG, Gu YF et al. Percutaneous sacroplasty for sacral metastatic tumors under fluoroscopic guidance only. Korean J Radiol 2008; 9: $572-576$

15 Georgy BA. Percutaneous cement augmentations of malignant lesions of the sacrum and pelvis. Am J Neuroradiol 2009; 30: 1357-1359

16 Sun G, Jin P, Liu XW et al. Three-dimensional C-arm computed tomography reformation combined with fluoroscopic-guided sacroplasty for sacral metastases. Support Care Cancer 2012; 20: 2083-2088
17 Kortman K, Ortiz O, Miller T et al. Multicenter study to assess the efficacy and safety of sacroplasty in patients with osteoporotic sacral insufficiency fractures or pathologic sacral lesions. J NeuroIntervent Surg 2013; 5: 461 - 466

18 Basile A, Tsetis D, Cavalli $M$ et al. Sacroplasty for local or massive localization of multiple myeloma. Cardiovasc Intervent Radiol 2010; 33: $1270-1277$

19 Valencia-Anguita J, Julia-Narvaez M, Rodriguez-Burgos F et al. Percutaneus sacroplasty for relieving pain caused by sacral metastases. Neurocirugica (Astur) 2007; 18: 247-249

20 Uemura A, Matsusako M, Numaguchi Y et al. Percutaneous sacroplasty for haemorrhagic metastases for hepatocellular carcinoma. Am J Neuroradiol 2005; 26: $493-495$

21 Atalay B, Caner H, Yilmaz C et al. Sacral kyphoplasty for relieving pain caused by sacral hemangioma. Spinal Cord 2006; 44: 196-199

22 Bastian JD, Keel MJ, Heini PF et al. Complications related to cement leakage in sacroplasty. Acta Orthop Belg 2012; 78: 100-105

23 Barber SM, Livingston $A D$, Cech DA. Sacral radiculopathy due to cement leakage from percutaneous sacroplasty, successfully treated with surgical decompression. J Neurosurg Spine 2013; 18: 524-528

24 Klingler JH, Sircar R, Deininger MH et al. Vesselplasty: A new minimally invasive approach to treat pathological vertebral fractures in selected tumor patients - preliminary results. Fortschr Röntgenstr 2013; 185: $340-350$

25 Binaghi S, Guntern D, Schnyder P et al. A new, easy, fast, and safe method for CT-guided sacroplasty. Eur Radiol 2006; 16: 2875-2878

26 Smith DK, Dix JE. Percutaneous sacroplasty: long axis injection technique. Am J Roentgenol 2006; 186: $1252-1255$

27 Frey ME, DePalme MJ, Cifu DX et al. Percutaneous sacroplasty for osteoporotic sacral insufficiency fractures: a prospective, multicenter, observational pilot study. Spine 2008; 8: 367-373

28 Andresen R, Radmer S, Kamusella P et al. Treatment of Denis 1, 2 and 3 insufficiency fracture zones of the os sacrum. Individual approaches adapted to the course of fracture in CT-assisted balloon sacroplasty. Osteol 2012; 21: $168-173$

29 Strub WM, Hoffmann M, Ernst RJ et al. Sacroplasty by CT and fluoroscopic guidance: is the procedure right for your patient? Am J Neuroradiol 2007; 28: $38-41$

30 Pommersheim $W$, Huang-Hellinger F, Baker $M$ et al. Sacroplasty: a treatment for sacral insufficiency fractures. Am J Neuroradiol 2003; 24: $1003-1007$

31 Briem D, Grossterlinden L, Begemann PG et al. CT-gesteuerte Sakroplastie unter Verwendung insufflierbarer Ballons: Ergebnisse einer Machbarkeitsstudie. Unfallchirurg 2008; 111: 381-386

32 Nader R, Rhines LD, Mendel E. Metastatic sacral tumors. Neurosurg Clin N Am 2004; 15: $453-457$

33 Toro A, Pulvirenti E, Manfrè L et al. Sacroplasty in a patient with bone metastases from hepatocellular carcinoma. A case report. Tumori 2010; 96: $172-174$

34 Dehdashti AR, Martin JB, Jean B et al. PMMA cementoplasty in symptomatic metastatic lesions of the $\mathrm{S} 1$ vertebral body. Cardiovasc Intervent Radiol 2000; 23: 235-237

35 Daubner D, Seifert J, Stroszczynski C. CT-Fluoroskopie-gestützte perkutane Sakroplastie zur Behandlung einer pathologischen Fraktur bei Osteoradionekrose. Fortschr Röntgenstr 2008; 180: 345 - 355

36 Quraishi NA, Giannoulis KE, Edwards KL et al. Management of metastatic sacral tumors. Eur Spine J 2012; 21: 1984 - 1993 